\title{
The Effectiveness of Group Acceptance and Commitment Therapy on Self- Efficacy and Social Adjustment of Elderly Retired
}

\author{
Bagheri $\mathrm{P}^{1}$, Saadati $\mathrm{N}^{2}$, Fatollahzadeh $\mathrm{N}^{3 *}$, Darbani S. $\mathrm{A}^{4}$
}

\begin{abstract}
Introduction and purpose: Due to the rapid increase in the senior population, health issue, health $\&$ provide comfort and welfare of society \& wider finds new dimensions every day. This study aimed to evaluate the effectiveness of acceptance and commitment therapy Retired adults was conducted on selfefficacy and social adjustment.

Material and Methods: The research method was quasi-experimental with pretest-posttest design with a control group. Study population included all patients older retired In the summer of 1395 was the organization of retirees. After the interview and questionnaire implementation of self-efficacy and social adjustment Of the 24 eligible voters agreed to participate in research Randomly divided into two groups (12 experimental and 12 control) Were replaced. acceptance and commitment therapy was administered to the experiment group in eight 90 minutes sessions in 4 weeks period. All participants before and after treatment questionnaires Self-efficacy and social adjustment completed.
\end{abstract}

Findings: The results of analysis of covariance showed that based on acceptance and commitment therapy Significant effect on self-efficacy $(\mathrm{F}=10.16, \mathrm{P}=0.005)$ and social compatibility $(\mathrm{F}=22.44, \mathrm{P}=0.001)$. It also reduces the subscales of family $(\mathrm{F}=29.78, \mathrm{P}=0.000)$, physical $(\mathrm{F}=4.71, \mathrm{P}=0.04)$, emotional $(\mathrm{F}$ $=14.26, \mathrm{P}=0.002)$, social $(\mathrm{F}=21.34, \mathrm{P}=0.000)$ and work $(\mathrm{F}=42.66, \mathrm{P}=0.000)$.

Conclusion: As a result, based on acceptance and commitment therapy can reduce self-efficacy and social adjustment.

Keywords: Acceptance and Commitment Therapy, self-efficacy, social adjustment, Retired Adults

Received: 2017/01/7

Accepted: 2017/02/19

Copyright $(\odot 2018$ Quarterly Journal of Geriatric Nursing.This is an open-access article distributed under the terms of the Creative Commons Attribution international 4.0 International License(http://creativecommons.org/licenses/by /4.0/) which permits copy and redistribute the material, in any medium or format, provided the original work is properly cited.

1. M.A. in Clinical psychology, Islamic Azad University, Branch Khomein, Khomein, Iran

2. Ph.D. student in counseling, Islamic Azad University, Branch Isfahan (Khorasgan), Isfahan, Iran

3 *M.A. in Clinical psychology, Islamic Azad University, Branch Rodehen, Rodehen, Iran

(Corresponding Author): Email: nh_fatollahzadeh@yahoo.com

$4 \mathrm{PhD}$ student of counseling, Islamic Azad University, Branch Science and Research, Tehran, Iran 


\title{
اثربخشى أموزش كَروهى درمان مبتنى بر يذيرش و تعهد بر خودكار آمدى و سازَّارى اجتماعى سالمندان بازنشسته
}

\author{
يريسا باقرى '، نادره سعادتى '، نوشين فتحالهزاده"، سيد على دربانى
}

تاريخ دريافت مقاله: 11/ • / هوس|

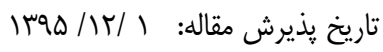

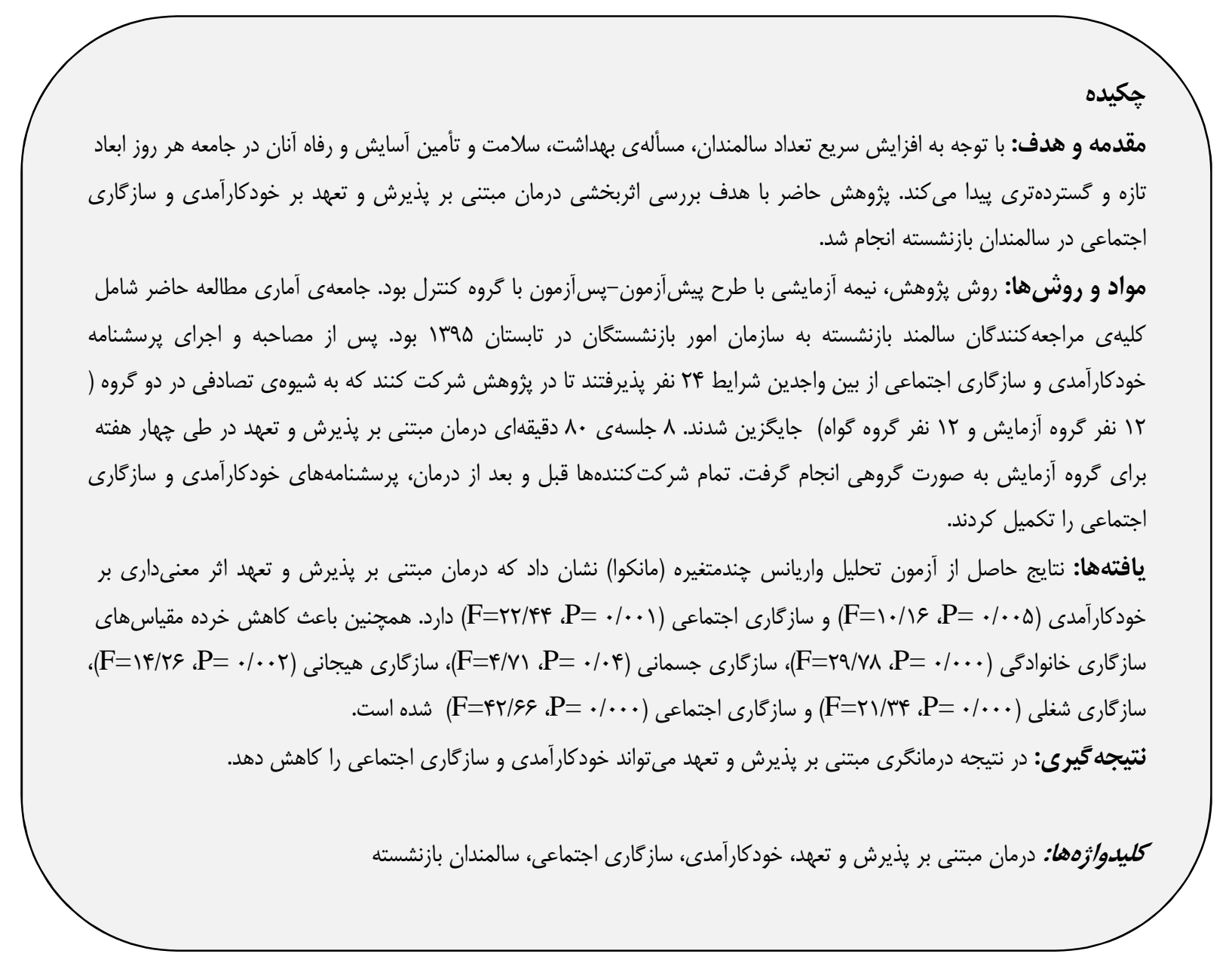

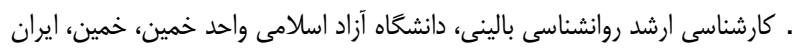

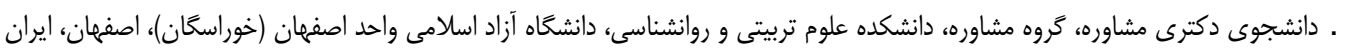

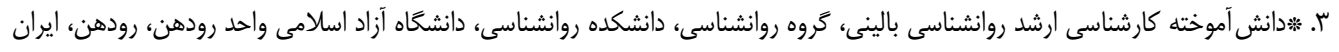

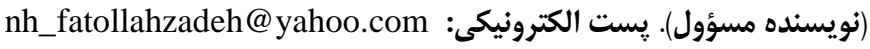
ـ دانشجوى دكترى مشاوره، كروه مشاوره، دانشكده علوم انسانى و اجتماعى، دانشكاه آزاد اسلامى واحد علوم و تحقيقات تهران، تهران، ايران 
ناميدى، اضطراب (مرك)، افسـردگى، عـدم سـازكَارى بـا وضـعيت جديد، حس ناكار آمدى و بـ كفايتى مى گردنــــ از ايـن رو، يكسى از مهمترين عواملى كه مىتواند پِس از بازنشستخى نيز باعث كـارايى، مفيد بودن، حس سـرزندگى و سـازگًارى بـا شـرايط موجـود شـود، احساس خودكارآمد بودن است. اصطلاح خودكارآمـدى مبتنى بـر نظريأ شناختى اجتماعى بندورا است. خودكارآمدى در واقع اعتقـاد راسخ فرد نسبت به توانايىهاى خود مىباشد كـه باعـث تحريـى انكَيزش و منابع شناختى فرد در رشـته اعمـالى كـهـ بــراى انجـام موفقيتآميز يك كار خاص لازم است، مىشود (ه).

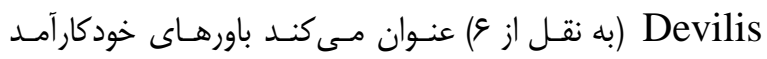
شناختهايى هستند كه باعث شروع تغييـرات رفتارهـاى سـلامتى مىشوند و همجنين موجب تلاش بيشتر در فرد و افزايش تحمـل فرد در مقابل موانع و همجنــين در مواقع شكسـت مسىــوند. در خودكارآمدى، اعتقاد فرد بر اين اسـت كـهـ فـرد بـهـ واسـطهى آن مىتواند رفتار لازم براى رسيدن به يك هدف مورد نظر را به طور موفقيتآميزى اجرا كند. جهار منبع اصلى داورى شـخص در مـورد خودكارآمدى خودش عبارتاند از: تجربيات موفق قبلى، تشـويق و ترغيب كلامى، تجربههاى جانشينى و انخيختكى فيزيولوزيكى (V). به جز انخيختخى فيزيولوزيكى، بقيلى منابع خودكارآمدى به شدت تحت تأثير جو خانوادكى فرد قرار دارند. خودكارآمـدى بـالا باعـث افزايش تلاش، پشتكار و انخيزش فردى مىشود و مؤثرترين عامل تعيين كننده عملكرد افراد بــه ويـزه در كنتـرل، يـايش و ييخيــى برنامهريزى يس از بازنشستخى اسـت (؟). از طرفـى خودكارآمـدى پايين، كمبود قدرتهاى تطابقى در فـرد بـراى مقابلـه بــا حـوادث
سالمندى يك فراينــد بيولـوزيكى اجتــابنايـذير اسـت كـه تمـام موجودات زنده را درگير مى كند و در برخى موارد همراه با تجربيـات ناخوشايند است (1). تحولات اجتماعى، اقتصادى و ييشـرفتهـاى علمى در سال هاى اخير موجب افزايش اميد به زندكى و كاهش نرخ مرگىمير شده است كه اين امر باعث افزايش جشمخير در جمعيت سالمندان شده است. تخمين زده مىشود كه جمعيت سـالمندان در جهان تا • أ سال آينده دو برابر خواهد شد (T). اين افزايش جمعيت در كشورهاى در حال توسعه به مراتب بيشتر از كشـورهاى توسـعه يافته است. ايران نيز به عنوان يكى از اين كشورهاى در حال توسعه از اين تغييرات جمعيتى مستثنى نيست؛ به كَونهاى كـه هـيشبينى مىشود جمعيت سالمندان از 1 درصد در سال • وجا به • ا درصد در

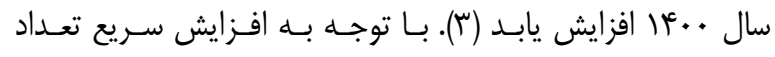
سالمندان، مسألدى بهداشت، سلامت و تأمين آسايش و رفاه آنان در جامعه هر روز ابعاد تازه و كستردهترى ييدا مى كند. به دليل اين كـه. در فرايند سالمندى، سيستمهاى مختلف بــن تحليـل مسرود و در عمل توانايىهاى انسان كاهش مىيابـد، سـالمندان دجـار افـزايش ناتوانى، كاهش استقلال و افزايش وابستخى به ديخـران و احسـاس عدم خودكار آمدى مىشوند. علاوه بر آن، اغلب مردان يير به دليـل اين كه از كار خود بازنشسته شدهاند و يا اين كه قدرت ارائهى كـار ندارند احساس از دست دادن مقام اجتماعى، نامنى، از كارافتادگى و تنهايى مى كنند. آنها اينَّونه تصور مى كنند كه كسى به آنها نياز ندارد و ديخران برايشان اهميتى قائل نيستند (أ). بنابراين طيف وسيعى از بازنشستخان، نتوانسته خـود را بـا وضـعيت كنونى سازكًار نمايند و در نتيجه دجار انواع مشكلات روانى از جمله 
از جمله درمانهاى ديخرى كه مىتواند در زمينهى بهبود سـلامت روانى و غنىسازى زندگى سالمندان تأثير گذار باشد، درمـان مبتسى بر يذيرش و تعهد است. درمان مبتنى بر קـذيرش و تعهـد يكى از الكَوهاى درمانى بسط يافتهى اخير اسـت كـه فراينـدهاى درمـانى كليدى آن با درمان شناختى رفتارى-سنتى متفاوت اسـت و اصـول زيربنايى آن شامل (الف) يذيرش يا تمايل به تجربهى درد و يا ديخر رويدادهاى آشفته كننده بدون اقدام به ممار آن و (ب) عمل مبتنى بر ارزش يا تعهد توأم با تمايل به عمل به عنوان اهـداف معنـدار شخصى بيش از حذف تجارب ناخواسته است كه در تعامل با ديخـر وابستخى هاى غير كلامى منجر به كاركرد سالم مىشود. ايـن روش شامل تجربيات تجربى و تمرينات مبتنى بر مواجهـه، اسـعارههـاى زبانى و روشهايى جون آموزش مراقبت ذهنى است (II). يذيرش و تعهد درمانى در سال ع 19 توسط Hayes ايجاد شد. اين روش قسمتى از موج سوم درمانهاى رفتارى است و به دنبـال موج دوم اين درمانها از قبيل درمان شناختى رفتــارى پِديـــــــــ. يذيرش و تعهد درمـانى بـا يــ برنامـهى تحقيقى تحـت عنـوان نظريهى نظام ارتباطى در ارتباط است. آشـكارا ايـن رويكـرد تغييـر كاركرد افكار و احساسات به جاى تغيير شكل، محتوا يا فراوانى آنها را مىيذيرد (T)). هدف اصلى، ايجاد انعطافيــيرى روانسى اسـت، يعنى ايجاد توانايى انتخاب عملى در بين ززينـهــاى مختلـف كـهـ متناسبتر باشد، نه ايـن كـه عملـى تنهـا جهـت اجتــاب از افكـار، احساسات، خاطرهها يا تمايلات آشفته ساز انجام يا در حقيقـت بــهـ فرد تحميل شود (זا). در اين درمان ابتدا سعى مىشود تا يـذيرش روانى فرد در مورد تجارب ذهنى (افكار و احساسات) افزايش يابد و متقابل آن، اعمال كنترلى نامؤثر كـاهش يابـــ. بــه مراجـع آموختـهـ مىشود كه هرَّونه عملى جهت اجتناب يا كنترل اين تجارب ذهنى
روزانهُ زندَّى مىتواند مقدمة ايجاد احساس ياس، ناكارآمدى و حس از كارافتادَى و تنهايى در سالمند بازنشسته شود (V). افزون بر آن، جنانجه كسى بتواند محدوديتهايش را بشناسـد، بِــيرد، راهــاى مقابله با آنها را بيابد و به كاربرد، اميال و آرزوهاى خود را محدود و كنترل نمايد و ارضاى آنها را تا حد امكان فراهم سازد، او را فردى سازكار كويند و از اين راه و در محدودهى آشكار و نهـان اجتمـاعى است كه ادامهى حيات و سلامت ميسر مىشود. برعكس اگر قادر به انجام اين كار نشود، او را ناساز گار گويند كه اجتماع به انحاء مختلف با او مقابله مى كند و از طريـق مختلـف، تنبيـهـ و در نهايـت طـرد و حذف مىشود. به اين دليل اسـت كـه سـازكًارى اجتمـاعى، داراى اهميت حياتى براى هر فردى است (^). سازكارى اجتماعى كـهـ بــهـ عنوان مهمترين نشانهى سلامت روان مطرحشده از جمله مبـاحثى است كه توجه بسـيارى از روانشناسـان بـهـ خصـوص روانشناسـان، مددكاران اجتماعى و مربيان را به خود جلب كرده و با حوزههـيى همجون سلامت عاطفى، اجتماعى، آموزشى، زناشويى و شغلى افراد مرتبط است (9). سازكارى امرى نسبى است و انسانها با درجـات مختلفى به سازًارى دست مىيابند. ساز كارى و هماهنكى با خود و محيط براى هر موجود زنده ضرورى اسـت و همــى تـلاشهــاى روزمرهى انسان توسط اين سازكارى تحت تأثير قرار مى رو، گَسترمى متنوعى از شيوههاى درمانى براى بازنشستخان داراى اختلال روانى مانند اضطراب، افسردگى و عدم سـازگًارى اجتمـاعى وجود دارد كه مهمترين آنها مداخلات روانشناختى از جمله شناخت درمانى، درمانهاى موج سوم، مصاحبه درمانى، درمان حل مســاله، درمـان بسين فـردى، درمـانهـاى روانيويـايى، كتـابدرمانى، خاطرهيردازى و درمان مرور زندگى و روايت درمانى (•). 
خودكارآمدى و سازگًارى اجتماعى در سـالمندان بازنشسـته را مـورد

مطالعه قرار دهد.

مواد و روشها

طرح اين يزوهش، نيمه آزمايشى از نوع بيش آزمون و يس آزمون با گروه كَاه است. در اين يثوهش جامعه آمارى را كليـه سـالمندان بازنشسته مراجعه كننده به سازمان امور بازنشستتىى در تهـران و در بازمى زمانى خرداد تا تيرماه هوسا شـامل مسىشـوند. از بـين كليـهـ سالمندان بازنشسته مراجعه كننده به سـازمان، سـالمندانى كـه واجــــ شرايط بودند و با توجه بــه مــلاكهــاى ورود بـهـ هـروهش: حـداقل تحصيلاتشـان ديـبلم بـوده، بـيش از r سـال از بازنشسـتخىشـان نحَذشته، در حال حاضر تحت درمـان دارويسى يـا رواندرمـانى قـرار

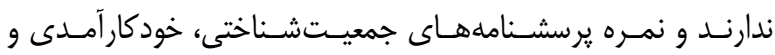
سازگًارى اجتماعى پايينى كسب كردهاند و فرم اعلام رضايت جهـت شركت در يزوهش را يـر كـرده بودنــــــــراى انتخــاب نمونـهـهـاى يزوهشى پِ از حضور در ساختمان مركـزى امـور بازنشسـتخان در خيابان فاطمى تهـران و مصـاحبه ابتـدايع بــا ســالمندان بازنشسـته مراجعه كننده جهت امور جارى، يّ از حائز بودن شرايط شـركت در يُوهش و پِ از كسب رضايت يرسشنامهها اجرا شد. طـى دو مـاه حضور و مصاحبه و اجـراى يرسشـنامه \&V سـالمند بازنشسـته كليـهـ شرايط شركت در يزوهش را دارا بودند. پِ از تماس با اين عزيزان و يادآورى و شرح ماهيت يزوهش و دعوت جهت شركت در يزوهش تنها وr نفر حاضر به همكارى شدند كـه از ايـن آب نفــر بـه مركـز مشاوره مهرآور مراجعه و در يزوهش شركت نمودند كه در دو حَروه آزمايش (ז ا نفر) و گَواه (r ا نفر) به صورت تصادفى كاربندى شدند. كروه آزمايش ^ جلسه آموزش مبتنى بر يذيرش و تعهـد بــهـ شـيوه گروهى را دريافت كردنـد، امـا حَروه حـواه مداخلـهاى را دريافت
ناخواسته بىاثر است يا اثر معكـوس دارد و موجـب تشـديد آنهــا مىشود و بايد اين تجارب را بدون هيجَّنه واكنش درونى يا بيرونى جهت حذف آنها به طور كامل يـــيرفت. در قـدم دوم بـر آَــاهى روانى فرد در لحظهى حال افزوده مىشود؛ يعنى فرد از تمام حالات روانى، افكار و رفتـار خـود در لحظـهـى حـال آَــاهى مسىيابـد. در مرحلهى سوم به فرد آموخته مىشود كه خود را از اين تجارب ذهنى جدا سازد (جداسازى شناخت)، به نحوى كـهـ بتوانـــــــــل از ايـنـ تجارب عمل كند. جهارم تلاش براى كاهش تمركز مفرط بر خـود تجسمى داستان شخصى (مانند قربانى بودن) كه فرد براى خـود در ذهنش ساخته است. ينجهم، كمك به فـرد تـا ايـن كـه ارزشهـاى شخصى اصلى خود را بشناسد و به طـور واضـح مشـخص سـازد و آنها را به اهداف رفتارى خاص تبديل كند (روش شناسى ارزشها). در نهايت، ايجاد انخيزه جهت عمل متعهدانه يعنى فعاليت معطوف به اهداف و ارزشهاى مشخص شده بـهـ همـراه پـــيرش تجـارب ذهنى. اين تجارب ذهنى مىتواند افكـار افسـرده كنتـده، وسواسـى، افكار مرتبط به حوادث (تروما) و هراسها باشند ( (أ و ها).

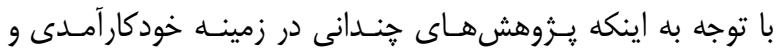
سازكارى اجتماعى سالمندان بازنشسته كه يكى از هشت مرحلـهى خرخdهاى زندگى خانوادگى مىباشد (ع)). صورت نخَرفته هدف از يزوهش حاضر اثربخشى درمان گروهى مبتنى بر يذيرش و تعهد بر خودكارآمدى و سازكارى اجتماعى در سالمندان بازنشسته مىباشد و جهت پاسخَكَويى به اين سئول به اجرا درآمد: كه آيا درمان كروهى مبتنى بر يذيرش و تعهد بر بهبود خودكارآمدى و سازكارى اجتماعى

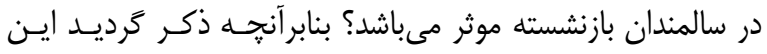
يُزوهش درصدد است طى فراينـدى علمى روى دو گَروه حَواه و آزمون، با استفاده از روش درمانى گروهى مبتنى بر يذيرش و تعهل، 
يرسشنامه با استفاده از كليد انجام مىشـود. در مطالعهى حاضـر از

خرده مقياس كَّ سؤالى سـازكًارى اجتمـاعى اسـتفاده شـد. Bell

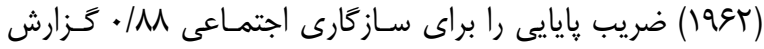
كرده است. نمرهى بالا در اين مقياس نشانهى دورى و كنارهيرى از تماس اجتماعى است. ايـن يرسشـامه توسـط بهرامى احسـان (اצrا، به نقل از • (T). بعد از ترجمه و ويرايش بر روى +.r نفر به صورت تصادفى اجرا شد. پايايى اين آزمون با روش آلفاى كرونبـاخ

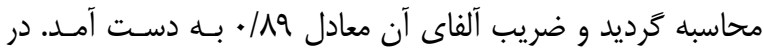

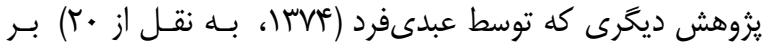
روى ها نفر از دانشجويان شاغل به تحصيل در مقطع كارشناسى ارشد دانشكاه مشهر صورت گرَفت، يايايى آزمون بـا روش ضـريب

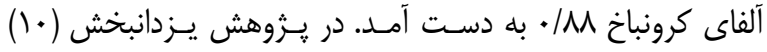
ضريب آلفاى كرونباخ محاسـبه و در حيطـهـى سـازكَارى هيجـانى، جسمانى، اجتماعى، خانوادگى، شـغلى و كـل بــه ترتيـب عبـارت از

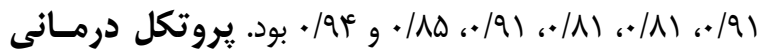
يذيرش و تعهد. در اين ثروهش سالمندان بـر اسـاس بسـتهى آموزشى كتاب درمانى مبتنى بر يـــيرش و تعهـــــــــى و عابـدى

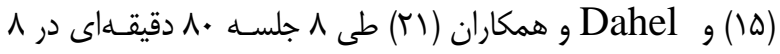
جلسه و ؤ هفته يِيايى (روزهاى شنبه و سهشنبه) مورد مداخلـه قـرار كرفتند كه خلاصُٔ محتواى هر جلسه در جدول ا ارائه شده است.
نكردند. جلسه به صورت هفتخى دو جلسه در روزهاى شـنبه و سـهـ شنبه به مدت •1 دقيقه و به صورت گروهى صورت گرفت. جهـت تحليل دادهها از آمار توصـيفى و آمـار اسـتنباطى (آزمـون تحليـل واريانس جند متغيره) استفاده شد. لازم به ذكر مىباشد كه به دليـل مسائل اخلاقى و همجِنين انخَيزه حضور در يزوهش بـه گَروه كَواه تعهد داده شد كه پֶس از پايان جلسات درمانى كروه آزمايش، آنهـا نيز تحت آموزش كروهى قرار خواهند كرفت.

"يرسشنامهٔ خودكار آمدى عمومى '! ايـن يرسشـنامه توسـط (IV)Schwarzer در •ا ماده تدوين شده است كه در مجمـوع بيانكر سازكارى موفقيتآميز فرد با يك موقعيت مشكلزا مىباشد. در مقابل هر عبارت، جهار گزينه كاملاً مخالف من، كمى شبيه من، خيلى شبيه من و كاملاً شبيه من قـرار دارد كـهـ بـهـ هـــر كـدام از كزينهها به ترتيب نمرات ا تأ تعلق مى گيـرد؛ بنـابراين، حـداقل نمره اين يرسشنامه براى هر فرد • ا و حـداكثر آن • أ مسىباشــ. اعتبار و پايايى اين يرسشنامه در مطالعات مختلف تأييد شده است. اين مقياس تك بعدى بر روى זّ فرهنَ اجرا شده است و نه تنها ساده و پاياست، بلكه داراى روايى افتراقى و همكرا نيز مىباشد. در

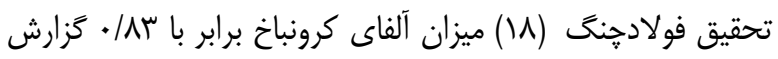
شده است. يرسشنامه سازكَارى اجتماعى بل .اين يرسشنامه توسط Bell (19) تدوين شد .او در زمينهى سازكارى دو يرسشنامه ارائه كرده است كه يكى مربوط به دانششآمـوزان و دانشـجويان و 19. ديخرى مربوط به بزركىسـالان اسـت. ايـن يرسشـنامه داراى سؤال و ينج خرده مقيـاس (سـازكَارى در خانـه، سـازكارى شـلى، سازگًارى تندرستى، سازگًارى عاطفى و سازكارى اجتماعى) اسـت. ياسخكويى به سؤالات به صورت بله خير و نمىدانم است. تصحيح

1 General Self-Efficacy Scale(GSE) 


\begin{tabular}{|c|c|c|}
\hline \multicolumn{3}{|c|}{ جدول خلاصه محتواى طرح درمانى بذيرش و تعهد } \\
\hline \multicolumn{2}{|c|}{ 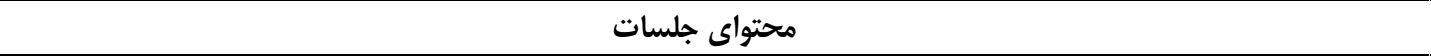 } & 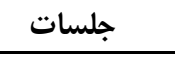 \\
\hline \multicolumn{2}{|c|}{ برقرارى رابطه درمانى، آشنا نمودن افراد با موضوع يُروهش، ياسخ به يرسشنامه و بستن قرارداد درمانى. } & 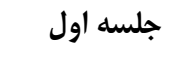 \\
\hline \multirow{2}{*}{\multicolumn{2}{|c|}{ تكليف. و بررسى روشهاى درمانى و ارزيابى ميزان تأثير آنها، بحث در مورد موقتى و كم اثر بودن درمانها با استفاده از تمثيل، دريافت بازخورد و ارائه }} & 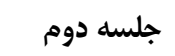 \\
\hline & & \\
\hline \multirow{2}{*}{\multicolumn{2}{|c|}{ 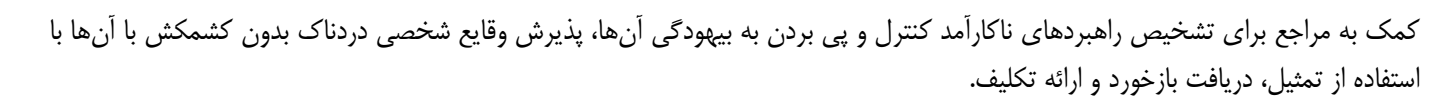 }} & جلسه سوم \\
\hline & & \\
\hline \multicolumn{2}{|c|}{ توضيح در مورد اجتناب از تجارب دردناك و آكاهى از ييامدهاى آن، آموزش كامهاى يذيرش، تغيير مفاهيم زبان با استفاده از تمثيل، آموزش تن } & جلسه جهارم \\
\hline & 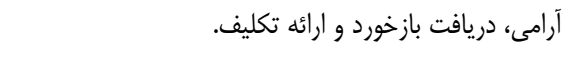 & \\
\hline \multirow{2}{*}{\multicolumn{2}{|c|}{ 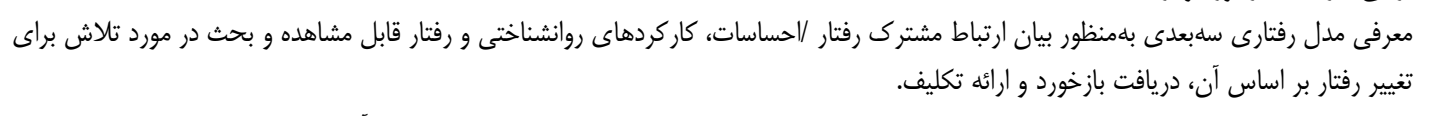 }} & جلسه ينجم \\
\hline & & \\
\hline \multirow{2}{*}{\multicolumn{2}{|c|}{ 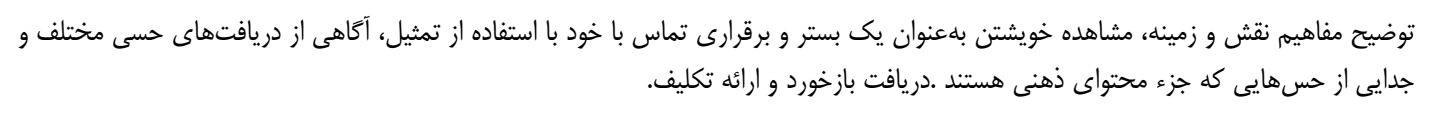 }} & 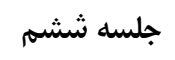 \\
\hline & & \\
\hline \multirow{2}{*}{\multicolumn{2}{|c|}{ 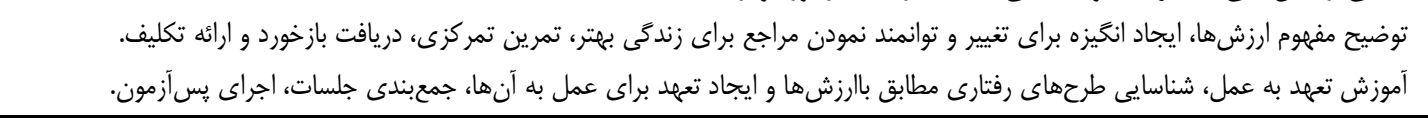 }} & جلسه هفتم \\
\hline & & جلسه هشتم \\
\hline \multirow[b]{2}{*}{ 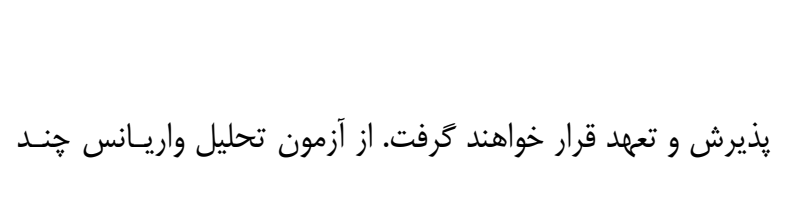 } & & روش اجرا \\
\hline & ات اصلى درمان، جلســاى بـــاى گَروه آزمـايش & 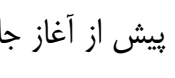 \\
\hline \multirow{2}{*}{ متغيره (مانكوا) براى تجزيه و تحليل دادهها استفاده شد. دادهها بـا } & ين جلسه تمـام قواعـــ و قـوانين ضـرورى گــروه & تشكيل شد و \\
\hline & إخر اين جلسه سعى شد تا حدودى افراد با هم تعامل & توضيح داده \\
\hline \multirow{3}{*}{ جدول r ميانگين و انحراف استاندارد نمرههاى آزمودنىهـاى گـروه } & هم صحبت كنند تا اضطراب اوليهى ورود به كروه & داشته باشند \\
\hline & ابد. درمان مبتنى بر يـذيرش و تعهـــ ( 1 جلسـهـ) & 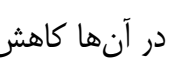 \\
\hline & ى •^م دقيقهاى براى كروه آزمايش اجرا شـد. بــ & هفتهاى دو > \\
\hline آزمايش و كَواه را در متغير احساس تنهايى و خرده مقياسهـايش در & ل اخلاق در يزوهش، شركت كنندًان آزاد بودند كه & \\
\hline 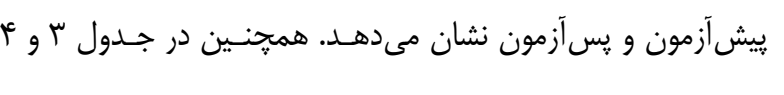 & مايل به ادامـهى درمـان، جلسـات را تـرى كنـــــ. & در صورت عد \\
\hline بر يذيرش و تعهد (ACT) بر ميـزان نمـرات احسـاس تنهـايى و & ل مسـائل اخلاقى و همجنــين انخيـزه حضـور در & 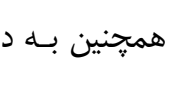 \\
\hline خرده مقياس هـايش در خَروه آزمـايش و گــواه در يـيش آزمـون و & كَواه تعهد داده شد كه پِ از پايان جلسات درمانى & 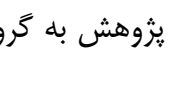 \\
\hline & ليز تحت آموزش كروهى درمان مبتنى بر & 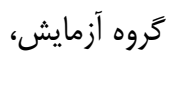 \\
\hline
\end{tabular}


جدول r دادهاى توصيفى نمرات خودكارآمدى و ساز تارى اجتماعى و مؤلفههايش در تروه آزمايش و تواه در بيش آزمون و پِسآزمون (ع (N=r)

\begin{tabular}{|c|c|c|c|c|c|c|}
\hline \multicolumn{2}{|c|}{ يسآزمون } & \multicolumn{2}{|c|}{ ييش آزمون } & \multicolumn{3}{|c|}{ شاخصهاى آمارى } \\
\hline انحراف معيار & ميانكين & انحراف معيار & ميانكين & كروه & & متغير \\
\hline $1 / \wedge \Delta$ & re/.. & $r / \mu \Lambda$ & سM/K & آزمايش & خودكار آمدى & \\
\hline I/VT & $r / / \Delta \Lambda$ & $1 / v \wedge$ & $|r| / 4$ & كواه & & \\
\hline .199 & $r \cdot / 4)$ & س9/. & $r \Delta / / Q$ & آزمايش & رى اجتماعى & نمره \\
\hline سז/1 & $r \Delta / r$. & I/ET & $r \Delta / r^{+}$ & كواه & & \\
\hline$\cdot / v 9$ & $\Delta / \Delta$. & $\cdot / M$ & $V / \& \&$ & آزمايش & خانوادگى & \\
\hline $1 / \cdot 1$ & $V / F 1$ &.$/ 9$. & $V / \Delta \Lambda$ & كواه & & \\
\hline .199 & $\varepsilon / \Delta \Lambda$ & $\cdot / V \Delta$ & $\Lambda / T \Delta$ & آزمايش & جسمانى & 2. \\
\hline$\cdot|\Delta|$ & $V / 41$ & $\cdot|\Delta|$ & $\mathrm{V} / \Delta \mathrm{A}$ & كواه & & $\$$ \\
\hline ./VD & $\kappa / T \Delta$ & .199 & $\varepsilon / \cdot \varphi^{f}$ & آزمايش & هيجانى & 3 \\
\hline $1 / \cdot 1$ & $9 / \cdot 1$ &.$/ 99$ & $s / r \Delta$ & كواه & & $\frac{3}{y}$ \\
\hline .190 & D/\&६ & $\cdot / V r$ & $V / \uparrow a$ & آزمايش & 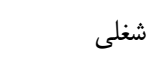 & 3 \\
\hline $1 / 48$ & glat & $1 / \uparrow \wedge$ & g/VQ & كواه & & v \\
\hline $1 / \cdot 1$ & $\Delta / \Delta$. & $1 / 14$ & $V / \Delta \Lambda$ & آزمايش & جتماعى & \\
\hline .190 & V/IT & $1 / \cdot 1$ & $V / r$. & كواه & & \\
\hline
\end{tabular}

با توجه به جدول ، ، نمرات احساس تنهايى گروه آزمايش از نمـرات مشاهده نمىشود. همجنين نمـرات خـرده مقيـاسهـاى خـانوادكى،

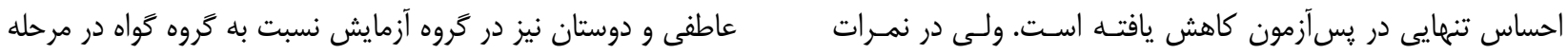

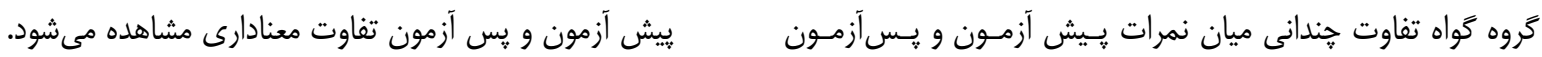

جدول ب نتايج آزمون تحليل واريانس جند متغيره (مانكوا) آموزش درمان مبتنى بر بذيرش و تعهد در خودكار آمدى و ساز كارى اجتماعى

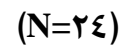

\begin{tabular}{|c|c|c|c|c|c|c|c|c|}
\hline توان & (اندازه اثر) & معنادارى سطح & $\begin{array}{c}\text { توزيع df } \\
\text { خطاى }\end{array}$ & df فرضيه df & آمار F & ارزش & اثر & \\
\hline.$/ D F$ &.$/ T \Delta$ & .1 .9 & 19 & $r$ & $r / 1 q$ & $\cdot / T \Delta$ & اثر بيلايى & مقدار \\
\hline$\cdot / D F$ & $\cdot \pi \Delta$ & .1 .9 & 19 & r & $r / 1 q$ & $\cdot / V^{e}$ & لانداى ويلكز & ثابت \\
\hline.$/ 99$ & .191 &.$\ldots$ & 19 & r & $|Q / \mu|$ &.$|9|$ & اثر ييلايى & تروه \\
\hline.$/ 99$ &.$|9|$ &.$/ \ldots$ & 19 & $r$ & $|Q / \mu|$ & . & لانداى ويلكز & \\
\hline
\end{tabular}

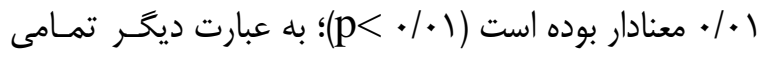
تقابلهـا و اثـرات بـين متغيرهـاى خودكارآمـدى و سـازكًارى

اجتماعى در سالمندان بازنشسته در مدل معنادار بوده است.
در جدول س مقدار هر كدام از دو آزمون نامبرده شده در جدول با آماره F نشان داده شده است كه مقدار تبديل شده آزمون F فوق اثر تمامى آزمونهاى نامبرده شده در سطح كوخىتـر از 
جدول ع نتايج تحليل واريانس جند متغيره (مانكوا) براى بررسى اثربخشى آموزش درمان مبتنى بر يذيرش و تعهد در خودكار آمدى و سازكارى اجتماعى (N) $(\mathrm{N}=\mathrm{r} \varepsilon)$

\begin{tabular}{|c|c|c|c|c|c|c|c|c|}
\hline آزوان & ضريب اتا انده اثر & معنادارى & آماره F F & ميانكين مجذورات & درجه آزادى & مجموع مجذورات & متغيرها & \\
\hline$\cdot / 9$ & $\cdot|r|$ & $.1 . r$ & D/DT & $r / \wedge q$ & 1 & $r / \wedge 9$ & خودكار آمدى & \\
\hline$\cdot / 11$ & .1 .9 & $\cdot / T V$ & $1 / T V$ & $\cdot / \Lambda$ & 1 & $\cdot / \Lambda$ & سازكَارى اجتماعى & مقدار ثابت \\
\hline$\cdot / \wedge \Delta$ & 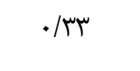 & $\% \infty$ & $1 . / 19$ & $V / 1 Q$ & 1 & $V / 1 Q$ & خودكار آمدى & تحروه \\
\hline.$/ 99$ & . / Q & $\cdot \%$ & $r r / 4 r$ & $1 \% / r e$ & 1 & $1 E / T e$ & سازَارى اجتماعى & \\
\hline - & - & - & - & - & r. & $\mid F / \cdot 1$ & خودكار آمدى & \\
\hline- & - & - & - & - & r. & $1 r / 99$ & سازكَارى اجتماعى & خطا \\
\hline - & - & - & - & - & re & $11 \cdot 9 \% / .$. & خودكار آمدى & كل \\
\hline- & - & - & - & - & re & $|\Delta T q| / .$. & سازكًارى اجتماعى & \\
\hline
\end{tabular}

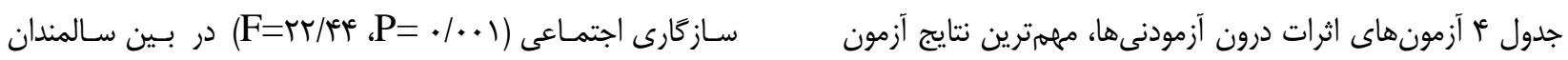
تحليـل واريـانس קنـــ متغيـره را شـامل مـىشـود. ايـن جـدول، بازنشسته معنادار بوده است؛ بنـابراين نتيجـه كرفتـه مسىشـود كـه

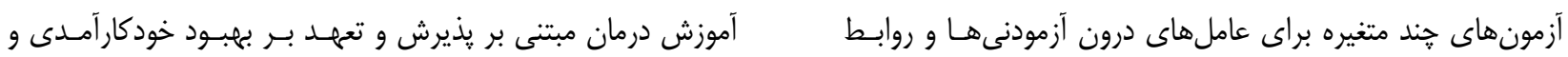
تقابلى بين آنها را نشان مىدهد. همان طور كه مشاهده مى كنيد در سازگًارى اجتماعى در تروه آزمايش اثر خذاشته است.

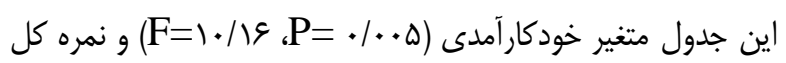

جدول ه نتايج آزمون تحليل واريانس جند متغيره (مانكوا) آموزش درمان مبتنى بر يذيرش و تعهد در مؤلفههاى سازًارى اجتماعى (ع=r)

\begin{tabular}{|c|c|c|c|c|c|c|c|c|}
\hline آزوان & (اندازه اثر) & معنادارى سطح & $\begin{array}{c}\text { توزيع df } \\
\text { خطاى }\end{array}$ & df فرضيه df & آمار F & ارزش & اثر & \\
\hline$\cdot / r \Delta$ &.$/ T A$ &.$/ 44$ & r & $\Delta$ & $1 / \cdot 1$ &.$/ T \Lambda$ & اثر ييلايی & مقدار \\
\hline$\cdot / r \Delta$ & $\cdot / T \Lambda$ &.$/ 44$ & rו & ه & $1 / \cdot 1$ & $\cdot / V 1$ & لانداى ويلكز & ثابت \\
\hline $1 / \cdot \cdot$ & $\cdot / \mathrm{AV}$ &.$\cdots$ & r & $\Delta$ & $\mid V / \Gamma^{\prime} \Delta$ & $\cdot / \mathrm{AV}$ & اثر ييلايى & تروه \\
\hline $1 / \cdot \cdot$ & $\cdot /$ AV &.$/ \ldots$ & rו & Q & $I V / \widetilde{L}$ & זו/. & لانداى ويلكز & \\
\hline
\end{tabular}




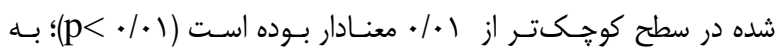

عبارت ديكر تمامى تقابلها و اثرات بين مؤلفههاى ساز كارى اجتماعى در

سالمندان بازنشسته در مدل معنادار بوده است.
Fر جدول ه مقدار هر كدام از دو آزمون نامبرده شده در جدول با آماره

نشان داده شده است كه مقدار تبديل شده آزمون F و يك توزيع تقريبى

از آن مىباشد. بر اساس مقادير جدول فوق اثر تمامى آزمونهاى نامبرده

\begin{tabular}{|c|c|c|c|c|c|c|c|c|}
\hline آزون & ضريب اتدازه اثر & معنادارى & آماره F & ميانكين مجذورات & درجه آزادى & مجموع مجذورات & متغيرها & \\
\hline 更 & .1 .4 & . & $\cdot / \Lambda$ &.$/ 1 r$ & 1 &.$/ 1 r$ & خانوادىى & \\
\hline$\cdot / \Delta F$ &.$/ \pi r$ & .1 .4 & $r / \Lambda$. & $1 / \pi T$ & 1 & $1 / \pi r$ & جسمانى & مقدار ثابت \\
\hline$\% \cdot v$ & .1 .1 & r & . & .0 & 1 & $.0 \Delta$ & هيجانى & \\
\hline.$/ . \infty$ &. & . $/ v a$ & $\cdot / \cdot v$ &.$/ 1$ & 1 & .1 .1 & شغلى & \\
\hline.$/ 1 r$ &.$\%$ &.$|F|$ &.$/ 99$ &.$/$ & 1 &.$/$ & اجتماعى & \\
\hline.$/ 99$ & שצr/. &.$/ \ldots$ & $r a / r \wedge$ & $r / \pi \Delta$ & 1 & $r / \pi \Delta$ & خانوادىى & كروه \\
\hline$\cdot \mid \Delta r$ &.$|r|$ & .1 .4 & $F / V$ & $1 / \pi$. & 1 & $1 / r$. & جسمانى & \\
\hline . /ar & $.1 \% \Delta$ & $\cdot / . . r$ & $\mid F / K q$ & $r / 1 \Delta$ & 1 & $r / 1 \Delta$ & هيجانى & \\
\hline.$/ 99$ & $\cdot / \Delta \Delta$ &.$\ldots$ & $r / \mu r$ & $f / l f$ & 1 & $r / 1 \%$ & شغلى & \\
\hline $1 /$. & $. / N)$ &.$/ \ldots$ & $\varphi r / s q$ & $g(\pi)$ & 1 & $g(\pi)$ & اجتماعى & \\
\hline - & - & - & - &.$/ 1 \infty$ & iv & $r / \Delta \Lambda$ & خانوادىى & \\
\hline - & - & - & - &.$/ \pi \Delta$ & iv & $r / r r$ & جسمانى & \\
\hline- & - & - & - &.$/ \pi r$ & iv & $r / v \Delta$ & هيجانى & خطا \\
\hline - & - & - & - &.$/ 19$ & iv & $r / \mu$. & شغلى & \\
\hline- & - & - & - &.$/ 1 F$ & iv & $r / F Y$ & اجتماعى & \\
\hline - & - & - & - & - & re & $|F| \psi \mid$. & خانوادىى & \\
\hline - & - & - & - & - & re & $|0| s \mid .$. & جسمانى & كل \\
\hline - & - & - & - & - & re & TTN/.. & هيجانى & \\
\hline - & - & - & - & - & re & $\mid T F F / T \Delta$ & شغلى & \\
\hline - & - & - & - & - & re & $\mid r r q / / \Delta \Delta$ & اجتمىى & \\
\hline
\end{tabular}


يكيارجگى شخصيت فرد مىشود و فرد طى فرايند يذيرش و تعهـــ ويزَى هاى ناشناخته و كارهاى ناكَتهى زندَّىاش را براى ديخران آشكار مىسازد و در جواب، آنها نيز ممكن است واقعيات و حقايق ينهانى را بيان كنند. اين آشكارسازىها ممكن اسـت باعـث تغييـر

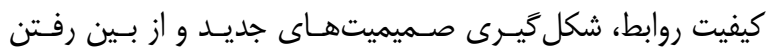

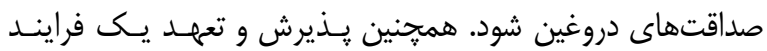
درمانى است كه باعث افزايش بينش و درك خود شده و با تغييـرات رفتارى، عاطفى و شناختى همراه است ومى تواند باعث از بين رفتن

نفرتهاى وحشتناك و تعصبات خاص شود (•(1). بنابراين مىتوان نتيجه گرفت كه يذيرش و تعهد در مجموع باعـث

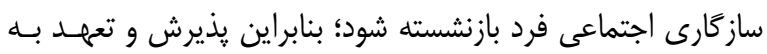
خودى خود، يك فرايند درمانى است كـه منجـر بــه بيـنش و درى بيشتر از خود، همراه با تغييرات عاطفى، رفتارى و شــاختى شــه و اين امر موجب سازكارى بيشتر فرد مىشود. غالباً افرادى كه از نظـر روانى سالم هستند، سعى مى كنند در عين رويارويى با امـور عـادى زندگى روزانه، موقعيتهاى ناراحت كننده را نيز رفع كنـــ. نحـوهى ياسخ افراد به محركهاى ناراحت كننده، انعكـاس تجـارب مختلـف زيستشناختى، روانى و فرهنخـى اجتمـاعى آنهاســ؛ امـا وقتـى استرس، توانايى فرد براى انجام كارها با آسودگى را مختل كـرده و مانع رفع نيازهاى فرد مىشود، او را در معرض مسائل هيجانى قرار مىدهد. استفاده از روشهاى غير مؤثر و ناسالم مقابلـه، در رفتارهـا، افكار و احساسات غيرعادى انعكاس ييدا مى كند. اين رفتارها كه بـاـا هدف تسكين استرس شديد انجام مىشود، ممكن است به مسـائل بعدى منجر شود (ع)).
جدول 8 آزمونهاى اثرات درون آزمودنىها، مهمترين نتايج آزمـون تحليـل واريـانس جنـــــنغيــه را شـامل مســـود. ايـن جـدول، آزمونهاى جند متغيره براى عاملهاى درون آزمودنىهـا و روابـط تقابلى بين آنها را نشان مىدهد. همانطور كه مشاهده مى كنيد در

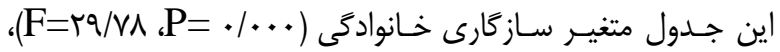

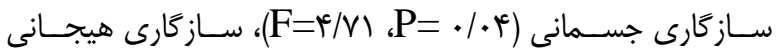

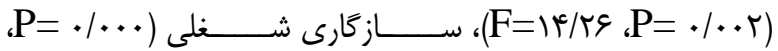
ז F سالمندان بازنشسته معنادار بوده است؛ بنابراين نتيجه گرفته مى شود

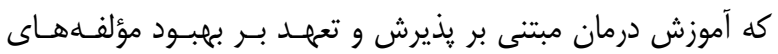
سازگًارى اجتماعى در گَروه آزمايش اثر كَاشته است.

\section{بحث و نتيجل كيرى}

اين يزوهش با هدف اثربخشى آمـوزش گروهـ درمـان مبتنى بـر يذيرش و تعهـــ بــر افـزايش خودكارآمـدى و سـازكًارى اجتمـاعى سالمندان بازنشسته انجام شد. نتـايج نشـان داد كـهـ روش درمـانى مبتنى بر يذيرش و تعهـــــــر خودكارآمـدى و سـازگًارى اجتمـاعى سالمندان بازنشسته تـأثير دارد كـهـ ايـن نتيجـهـه بـا نتـايج هـروهش

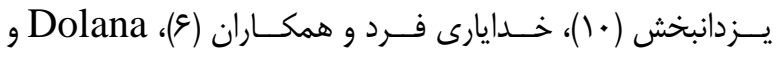

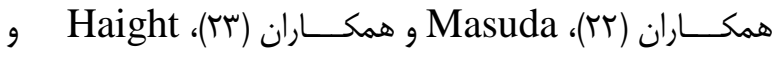
همكـاران (T) Mackinlay \& Trevitt مىباشد. در تبيين اين نتيجه مىتوان كفـت كـه درمـان مبتــى بـر يذيرش و تعهد با احياى تجارب و تعارضات، باعـث ارزيـابى مجـدد آنها، حل تعارضات، جمعبندى دوباره آنهـا و در نتيجـهـ انسـجام و 
و همجنين فنون استفاده شده در اين درمان، به نظر قابـل توجيـهـ

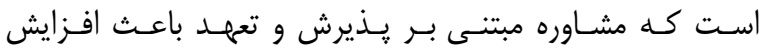
خودكار آمدى در سالمندان بازنشسته شود (Tr).

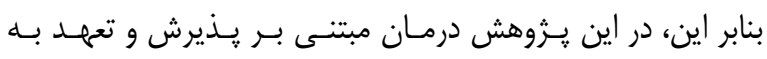
بازنشستخان كمى كرد تا تجربيات كذشته خودشان را با خشـنودى منعكس سازند و ثبات روانى به دست آورند. نظريهِـــدازان وحـدت خود و يكِارجهازى نيز موافقاند كه بذيرش و تعهد با رشد هويت فردى مرتبط است و باعث حفظ رابطهى حـوادث كذشـته بـا خـود

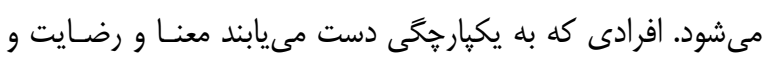
خشنودى از زنــدى دارنــــ و ايـن رضـايت باعث خودكارآمـدى و ساز كارى بيشتر آنان مى كردد و همجنين شخصى كـه بـا موفقيـت

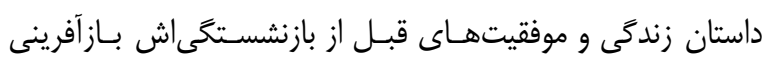
مىشود، كمتر در برابر افسردگى، احساس بى كفايتى و ناكارآمد بودن آسيبيذير است (•). Mackinlay \& Trevitt دادند كه مرور خاطرات موفق كذشته و يذيرش شرايط فعلى موجب معنى يافتن هويت فردى، احساس لـذت و شـادى، رفـع غمخَينى، نغرانى و احساس كَناه و كاه موجب رسيدن به يـك درى جديـد از خود در سالمندان مىشود؛ بنابراين احساس انسجام بر اثر نخـاه بــــ زندگى كذشته و يذيرش شرايط موجود، به دست مىآيـد كـه ايـن فراينــد در مجمـوع منجــر بــهـ افـزايش خودكارآمـدى و سـازكارى اجتماعى مى شود. جامعه يزوهش حاضر محدوديتهايى را در زمينه تعميم ايجاد مى كند كه ييشنهاد مى شود اين يزوهش در جوامع ديخر

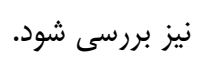

Masuda افكار خود انتسابى منفى كه يك نمونه از اين افكار، افكار مربوط به خودكارآمدى است را بررسى كردند و نتايج كـاهش خشـمخيرى در مقدار اين افكار با استفاده از تكنيكهاى گسلش شناختى نشان داد. احتمال مىرود خودشناسى مبتنى بر ارزشها و بازسـازى آنهـا در كـاهش افكـار خـود انتسـابى منفـى مـؤثر بـوده اسـت. همجنــين و هolana مورد مطالعه قرار دادند نتايج نشان دهنده ارتباط قوى خودكارآمدى در موقعيتهاى مختلـف بـود. همـان طـور كـه Dikelmente (1991؛ به نقل از 9) عنوان مى كند كه كسانى كه اطمينان كمترى به توانايى خود در انجام رفتارهايى مانند سازكارى با شرايط جديـد، احساس كارا بودن و مفيد بودن و غيره دارند، ممكن است در مرحله ييش تأملى يا ناآكاهى گير كنند و از بابت احتمـال تغييـر احسـاس ناميدى كنند. براى اينكه فرد سرخورده از وضعيت كنونى از مرحله عزم و آمادكى به مرحله اقدام و ابقاء برســ، بايـــ خودكارآمـدى و اطمينان به خود، در او تقويت شود. يكى از مراحل مهم در اكثريت مشاورهها، به خصوص مشاوره مبتنى بر يذيرش و تعهد، بر عهبده كرفتن مسئوليت درمان توسط مراجع مسىباشـــ. خودكارآمـدى بــــ نحوى ياسخ به اين سؤال است كه آيا من مىتوانم از عهده انجـام كار برآيم يا نه. مشاوره يذيرش و تعهد با دادن تكـاليف مناسـب و كار روى ارزشها مىتواند خودكارآمدى را در افراد افزايش مىدهد.

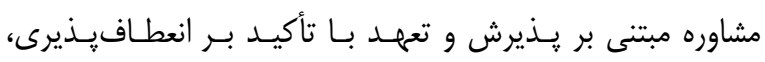
شفافسازى ارزشها و بحث روى اين موضوع كه تغيير امكانيذير

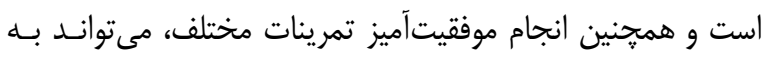
افزايش خودكارآمدى و يذيرش مسئوليت مشاوره توسط مراجع مؤثر باشد. با توجه به ويزَگىهاى خاص مشاوره مبتنى بر يذيرش و تعهد 


$$
\begin{aligned}
& \text { تقدير و تشكر } \\
& \text { از تمامى شركتكنندكان محترم در يزوهش و مــير مركـز مشـاوره }
\end{aligned}
$$

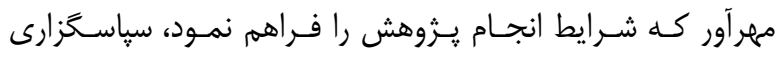

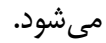

- References

1. Fakhri F.R., \& Hashemi M. A. A Qualitative Research: Postmenopausal Women's Experiences of Abuse. Procedia-Socialand Behavioral Sciences, 2013; 82, 57-60.

2. Oh J., Kim H. S., Martins D., \& Kim, H. A study of elder abuse in Korea. International Journal of Nursing studies, 2006; 43(2), 203-214.

3. Khalili G., Holiness M., Heravi M., Sadrollahi., \& Gilasi H. F. Evaluate the relationship between depression and the abuse of older people living in Kashan. Journal of elderly. 2015; 10 (4): 21-35. (Persian)

4. Melzer D., McWilliams B., Brayne C., Johnson T., \& Bond J. Profile of disability in elderly people: Estimates from a longitudinal population study. British Medical Journal, 1999; 318(7191), 1108-1111.

5. Shmaizadeh A. The effect of social cognitive career counseling entrepreneurial self-efficacy of university students. (Master's thesis advisers), Islamic Azad University of Isfahan. 2005. (Persian)

6. Khodayari Fard M, Hejazi A, and Houseini nezhad N. The effectiveness of cognitive-behavioral advice based on Acceptance and Commitment (ACT) on the efficacy and marital satisfaction in women addicted to drug abuse has a wife and children. Journal of Applied Psychological Research. 2005; 6 (2), 61-75. (Persian)

7. Habibi R, Kareshki H, Dashtgard S, Heydari Ali, \& Talai A. Efficacy Questionnaire validation and reliability analysis. Hakim Research scientific journal.2012; 15 (1): 53-59. (Persian).

8. Hassanzadeh L. Positive self-talk to increasing the effectiveness of social adjustment of secondary school students in the city of Babolsar. (Dissertation Master's) Tabatabai University,Tehran.2010. (Persian)

9. Hamidi F, \& Mohamad Hosseini Z. The Relationship between Irrational Beliefs and Social, Emotional and Educational Adjustment among Junior Student. Journal of Social and Behavioral Sciences, 2010; 5, 1531-1536. (Persian)

10. Yazdanbakhsh K. Effects of life review on social adjustment of retirees' elderly persons. Journal of Aging Psychology 2016, 1(3): 179-185. (Persian) 
11. Vallis M, Ruggiero L, Greene G, Jones H, Zinman B, Rossi S, ... Prochaska J. O. Stages of change for healthy eating in diabetes: Relation to demographic, eating-related, health care utilization, and psychosocial factors. Diabetes Care, 2003; 2(5), 468-474.

12. Hayes S. C, Luoma J. B, Bond F.W, Masuda A, \& Lillis J. Acceptance and commitment therapy: Model, processes and outcomes. Behaviour Research and Therapy, 2006; 44(1), 1-25.

13. Forman E. M, \& Herbert D. New directions in cognitive behavior therapy: Acceptance based therapies, chapter to appear. In W. T. O'Donohue, J. E. Fisher, (Eds.), Cognitive behavior therapy: Applying empirically supported techniques in your practice (2nd ed.). Hoboken, NJ: John Wiley \& Sons.2009.

14. Kakavand A.R, Baqeri M.R, \& Shirmohamadi F. The Effectiveness of Acceptance and Commitment Therapy on Stress Reductionin Afflicted Elderly Men to Heart Diseases. Journal of Aging Psychology. 2016, 1(3): 169-178. (Persian)

15. Izadi R, \& Abedi M. Acceptance and Commitment Therapy. Tehran: Jungle.2013. (Persian)

16. Duvall E. M. Marriage and family development (5th ed). New York: Lippincott.1997.

17. Schwarzer R. Self-efficacy: Thought control of action. Washington, DC:Hemisphere.1992.

18. Fouladchang D. Evaluation of efficacy of female students in Fars province and provide appropriate solutions. Proceedings of weeks of research, education agency Fars province. 2003; 79-99. (Persian)

19. Bell H. M. The adjustment inventory: adult form. Palo Alto: Consulting Psychological Press.1962.

20. Fathi-Ashtiani A, \& Dastani D. Psychological tests, personality and mental health evaluation. Tehran: Besat. 2013. (Persian)

21. Dahl C, Stuart A, Martel K \& Kaplan C. ACT and RFT in relationships: helping clients eager for intimacy and maintain healthy obligations. Translation: Navabinejad Sh, Saadati N. and Rostami M. The first edition, Tehran: the Jungle.2015. (Persian)

22. Dolana S. L, Martin R. A, \& Rohsenowa D. J. Self-efficacy for cocaine abstinence: Pretreatment correlates and relationship to outcome. Addictive Behaviors, 2008; 33(5),675-688.

23. Masuda A, Hayes S. C, Sackett C. F, \& Twohig M. P. Cognitive defusion and self-relevant negative thoughts: examining the impact of a ninety year old technique. Behaviour Research and Therapy, 2004; 42(4), 477-485.

24. Haight B, Coleman P.G, \& Lord K. The linchpins of a successful life review: Structure, evaluation, and individuality. In Haight B. K., Webster J. D. (Eds.), The art and science of reminiscing: Theory, research, methods and applications. 1995; 179-192. Bristol, PA: Taylor \& Francis. 
25. Mackinlay E, \& Trevitt C. Living in aged care: Using spiritual reminiscence to enhance meaning in life for those with dementia. International Journal of Mental Health Nursing,2010; 19(6), 394401.

26. Fahimi far A. The effectiveness of life review therapy with a spiritual approach to increasing the quality of life and life satisfaction among cancer patients martyr Beheshti Hospital. (Master's thesis). Allameh Tabatabai University, Tehran. 2010. (Persian) 